\title{
Acaricidal and Antioxidant Activities of Anise Oil (Pimpinella anisum) and the Oil's Effect on Protease and Acetylcholinesterase in the Two-Spotted Spider Mite (Tetranychus urticae Koch)
}

\author{
Salwa M. El-Sayed ${ }^{1, *}$, Nevin Ahmed ${ }^{2}$, Samy Selim ${ }^{3, *(D)}$, Areej A. Al-Khalaf ${ }^{4}$, Nihal El Nahhas ${ }^{5}$ (D), \\ Shams H. Abdel-Hafez ${ }^{6}{ }^{D}$, Samy Sayed ${ }^{7}{ }^{D}$, Heba M. Emam ${ }^{8}$ and Mervat A. R. Ibrahim ${ }^{1}$
}

check for updates

Citation: El-Sayed, S.M.; Ahmed, N.; Selim, S.; Al-Khalaf, A.A.; El Nahhas, N.; Abdel-Hafez, S.H.; Sayed, S.;

Emam, H.M.; Ibrahim, M.A.R.

Acaricidal and Antioxidant Activities of Anise Oil (Pimpinella anisum) and the Oil's Effect on Protease and Acetylcholinesterase in the Two-Spotted Spider Mite (Tetranychus urticae Koch). Agriculture 2022, 12, 224. https://doi.org/10.3390/ agriculture12020224

Academic Editor: Roy Kennedy

Received: 13 January 2022

Accepted: 28 January 2022

Published: 3 February 2022

Publisher's Note: MDPI stays neutral with regard to jurisdictional claims in published maps and institutional affiliations.

Copyright: (C) 2022 by the authors. Licensee MDPI, Basel, Switzerland. This article is an open access article distributed under the terms and conditions of the Creative Commons Attribution (CC BY) license (https:// creativecommons.org/licenses/by/ $4.0 /)$
1 Department of Biochemistry, Faculty of Agriculture, Ain Shams University, Shoubra El-Kheima, P.O. Box 68, Hadayek Shoubra, Cairo 11241, Egypt; mervat_ibrahim@agr.asu.edu.eg

2 Plant Protection Department, Faculty of Agriculture, Benha University, Benha 13736, Egypt; nevin.ahmed@fagr.bu.edu.eg

3 Department of Clinical Laboratory Sciences, College of Applied Medical Sciences, Jouf University, Sakaka 72341, Saudi Arabia

4 Department of Biology, College of Science, Princess Nourah Bint Abdulrahman University, P.O. Box 84428, Riyadh 11671, Saudi Arabia; aaalkhalaf@pnu.edu.sa

5 Department of Botany and Microbiology, Faculty of Science, Alexandria University, Alexandria 21526, Egypt; nihal.elnahhas@alexu.edu.eg

6 Department of Chemistry, College of Science, Taif University, P.O. Box 11099, Taif 21944, Saudi Arabia; s.abdelhafez@tu.edu.sa

7 Department of Science and Technology, University College-Ranyah, Taif University, P.O. Box 11099, Taif 21944, Saudi Arabia; s.sayed@tu.edu.sa

8 Department of Plant Protection, Faculty of Agriculture, Ain Shams University, Shoubra El-Kheima, Cairo 11241, Egypt; hebasoliman@agr.asu.edu.eg

* Correspondence: salwa_sedeek@agr.asu.edu.eg (S.M.E.-S.); sabdulsalam@ju.edu.sa (S.S.)

Abstract: The two-spotted spider mite, Tetranychus urticae, also known as the red spider, is one of the most harmful pests in agriculture and causes large losses of many crops. These mites have rapidly developed a resistance to many chemical pesticides in recent years. In this study, the essential oil of seeds of the anise plant (Pimpinella anisum) was extracted by hydrodistillation, and the chemical composition of the oil was analyzed. The antioxidant activity of the volatile oil was determined by the DPPH radical scavenging assay. The acaricidal activity of the anise oil, a natural acaricide, was evaluated for its ability to protect green bean plants from mite injury. The two-spotted spiders were spread on green bean seedlings for 1 week; then, different plants were sprayed with different concentrations of anise oil $(10,20,30$, or $40 \mu \mathrm{L} / \mathrm{L})$. Our results revealed that anethole was the major component of anise oil, at 53.23\%. The acaricidal effect of the various concentrations on T. urticae was recorded after 24, 48, and $72 \mathrm{~h}$ of treatment. Our findings suggest that anise oil showed significant acaricidal activity against T. urticae in a dose- and time-dependent manner. Anise oil at a concentration of $40 \mu \mathrm{L} / \mathrm{L}$ killed $96.0 \%$ of the red spiders after $72 \mathrm{~h}$. Also, all concentrations of anise oil inhibited acetylcholinesterase, and the spiders' protease activity declined when the plants were treated with 30 or $40 \mu \mathrm{L} / \mathrm{L}$ of anise oil. The concentrations of 10 and $20 \mu \mathrm{L} / \mathrm{L}$ did not significantly affect the protease activity of T. urticae mites. We can conclude that anise oil exhibited acaricidal activity against T. urticae and that this was highly correlated with the inhibition of acetylcholinesterase and protease activities in the mites.

Keywords: Tetranychus urticae; acaricidal activity; Pimpinella anisum; anise oil; AChE; protease

\section{Introduction}

The two-spotted spider mite, Tetranychus urticae Koch (Acari family Tetranychidae), is a harmful pest that damages many crops, including vegetables, fruits, and ornamental plants [1]. It is also the most common plant-eater of the family Tetranychidae [2], attacking 
3877 host crops of both greenhouse and field crops [1]. The two-spotted spider mite is polyphagous; it can feed on hundreds of plants, including many that are important for the economic well-being of countries. In controlling this pest, the main option is the use of synthetic acaricides, but they are not always efficient, because this species has a high ability to develop resistant populations [3], and because these acaricides are not selective for predatory mites [4]. The improper use of these agents can result in environmental and food contamination, especially of fruits and vegetables meant to be consumed when freshly harvested [5]. Chemical acaricides such as organophosphorus compounds, synthetic pyrethroids, and amitraz are used to control mites. Recently, many acaricides have been replaced with newer, safer agents owing to the toxicity resistance of and environmental damage caused by earlier agents [6]. Several essential oils were evaluated for their acaricidal activities. Essential oils consisting of volatile secondary metabolites, mostly terpenes [7], act as botanical insecticides [8,9], some of which are marketed as commercial ingredients for pesticides [10]. Many essential oils are used as insecticides due to their direct effects, biodegradability, and low level of toxicity to mammals [10-12]. Also, these natural compounds have very low toxicity in humans, making them good alternatives to synthetic acaricides. These essential oils, including anise oil, contain many natural compounds that have acaricidal activity $[8,9]$. The insecticidal and acaricidal activities of anise oil could be attributed to their terpenoidal content [7]. As previous studies have shown, the toxicity of anise oil against insect pests is due to its active ingredients, such as (e)-isoeugenol, limonene, linalool, and $\alpha$-pinene [13,14]. Amini et al. [14] identified the components of essential oils and showed that Pimpinella anisum L. had the most fumigant toxicity against the storage pests. Anise insecticidal activity was also studied by Tunç and Sahinkaya [15], who verified some anise acaricide activity against Tetranychus cinnabarinus Boisd. On fumigation tests, Lucca et al. [16] reported that an important potential insecticidal characteristic of anise was that it repelled moths. Anethole phenylpropanoid, the most important component of anise, was very efficient in controlling Aedes aegypti and Culex pipiens L. mosquitoes [17]. The volatile essences (monoterpenes) attract insects, mainly sucking insects, due to their nutrimental attributes [18]. Koul et al. [19] reported that the efficiency of essential oils such as anise is variable and depends on the presentation, application, and concentration of the metabolite used. In the attempt to identify alternatives with less environmental impact for the control of the two-spotted spider mite, this study aimed at evaluating the acaricidal effect of anise oil on females of this species, including the maximal lethal concentrations of the oil. It also investigated the relationship between the acaricidal activity of anise oil and its inhibitory effect on spider protease and acetylcholinesterase (AChE) activities.

\section{Materials and Methods}

\subsection{Materials}

The seeds of the anise plant (P. anisum L.) were purchased from the local market in Cairo, Egypt. The substances 1,1-diphenyl-2-picrylhydrazyl (DPPH); butylated hydroxyanisole (BHA); 5,5-dithiobis (2-nitrobenzoic acid) (DTNB); acetylthiocholine iodide (ATCh); and bovine serum albumin (BSA) were purchased from the Sigma-Aldrich Chemical Co (Taufkirchen, Germany). All reagents used throughout this study were of analytical grade.

\subsection{Extraction of Essential Oil of Anise}

The essential oils of dried anise seeds ( $200 \mathrm{~g}$ ) were isolated by steam distillation for $3 \mathrm{~h}$ using a glass Clevenger-type apparatus. The extracted yellow-colored volatile oils were dried over anhydrous $\mathrm{Na}_{2} \mathrm{SO}_{4}$ and were kept at $4{ }^{\circ} \mathrm{C}$ in dark glass vials for further analysis.

\subsection{Gas Chromatography-Mass Spectrometry (GC-MS) Analysis}

After evaporation, the extracted oil residue was dissolved with $3 \mathrm{~mL}$ ethyl acetate and $1 \mathrm{~mL}$ transferred to GC vial for GC/MS analysis. Gas chromatography-mass spectrometry was used for the analysis of various components of anise volatile oil that were present in 
modest quantities, in addition to the analysis of the main components of anise essential oil. The identification of components was based on a comparison of their mass spectra and retention time with those of the authentic compounds and by computer matching with the NIST and WILEY libraries as well as by comparison of the fragmentation pattern of the mass spectral data with those reported in the literature. The analysis was carried out using a GC (Agilent Technologies 7890A, Poway, CA) interfaced with a mass-selective detector (MSD, Agilent 7000, Poway, CA) equipped with a polar Agilent HP-5 ms (5\%-phenyl methyl poly siloxane) capillary column (30 $\mathrm{m} \times 0.25 \mathrm{~mm}$ i.d. (In diameter) and $0.25 \mu \mathrm{m}$ film thickness). The carrier gas was helium with a linear velocity of $1 \mathrm{~mL} / \mathrm{min}$. The injector and detector temperatures were $200{ }^{\circ} \mathrm{C}$ and $250{ }^{\circ} \mathrm{C}$, respectively. Volume injected was $1 \mu \mathrm{L}$ of the sample. The MS operating parameters were as follows: ionization potential $70 \mathrm{eV}$, interface temperature $250{ }^{\circ} \mathrm{C}$, and acquisition mass range 50-800 [20].

\subsection{DPPH Free Radical Scavenging Activity}

The capacity of essential anise oil to scavenge the DPPH (1,1-diphenyl-2-picrylhydrazyl) radical was determined according to the method described in [21]. Butylated hydroxyanisole (BHA) was used as a reference. In the DPPH method, $500 \mu \mathrm{L}$ of freshly prepared of DPPH solution (50 $\mu \mathrm{M}$ in absolute ethanol) was mixed with $300 \mu \mathrm{L}$ of anise oil $(10-50 \mu \mathrm{L} / \mathrm{L})$ and left in the dark for $30 \mathrm{~min}$. Then, the absorbance of the mixture was recorded at $517 \mathrm{~nm}$. The capability to scavenge the DPPH radical (\% inhibition) was calculated using the following equation: \% inhibition $=\left[\left(A_{c}-A_{t}\right) / A_{c}\right] \times 100$. Where $A_{c}$ is the absorbance of the reaction without sample (control) and $A_{t}$ is the absorbance of test samples.

\subsection{Mite Rearing}

One adult female mite was transferred by a fine camel hair brush to a sweet leaf disc ( $1 \mathrm{~mm}$, in diameter), preserved on a humid cotton wool pad in a Petri dish, and left for $24-48 \mathrm{~h}$ to allow it to lay eggs. The deposited eggs were preserved under laboratory conditions at $27 \pm 2{ }^{\circ} \mathrm{C}, 60 \pm 5 \%$ R.H. (Realtive Humidity) and $16 \mathrm{~L}$ : 8 D photoperiod until hatching. The newly hatched larvae were transferred singly to fresh sweet potato leaves to follow their development. Distilled water containing $0.01 \%$ Tween 80 was used to prepare the five dilutions of anise oil as an emulsifier and to make it slightly sticky. Distilled water containing $0.01 \%$ Tween 80 was used as a control [22].

\subsection{Acaricidal Activity of Anise Oil against Tetranychus Urticae under Laboratory Conditions}

Four concentrations of the essential oil were used in the experiment $(10,20,30$, and $40 \mu \mathrm{L} / \mathrm{L}$ ), and an untreated control group was prepared under laboratory conditions of $27 \pm 2{ }^{\circ} \mathrm{C}$ and $60 \pm 5 \%$ relative humidity to evaluate the eggs and adult females of the two-spotted spider mite. The concentrations of the essential oil were chosen based on previous studies and the effectiveness of similar plants on other spiders. Thirty adult females and 120 eggs of T. urticae were chosen and used per three replicates. Each group was transferred to a leaf disc of $4 \mathrm{~cm}^{2}$ in area, which was placed upside down on moist cotton wool in a Petri dish. Each leaf disc had 5 female mites and 20 mite eggs on it. Two $\mathrm{mL}$ of each concentration of the anise oil was sprayed onto the surface of the leaf discs using a hand-held atomizer at a distance of 25 to $30 \mathrm{~cm}$. The replicates of the eggs and adult females and the control were sprayed with distilled water containing $0.01 \%$ Tween 80 . After 24,48 , and $72 \mathrm{~h}$, the numbers of live and dead adult females were counted. The numbers of hatching eggs also were counted over 6 days by a dissecting microscope. The percentage of mites that had died was calculated and corrected according to Abbott's formula [23].

The values of $\mathrm{LC}_{50}$ and $\mathrm{LC}_{90}$ were determined using the mortality regression lines drawn according to the Finney, 1952 [24] method and the Sigmaplot program version 2.0 software [25]. 


\subsection{Determination of Enzyme Activities}

Adult females of the two-spotted spider mite were homogenized at $4{ }^{\circ} \mathrm{C}$ in a $0.066 \mathrm{M}$, pH 7.5 sodium phosphate buffer with 0.2 percent $(v / v)$ of Triton X-100. The mixture was centrifuged at $10,000 \times g$ at $4^{\circ} \mathrm{C}$ for $15 \mathrm{~min}$. The protease and acetylcholinesterase activity were measured in supernatants.

\subsection{Assay of Protease Activity}

The activity of proteases in the whole mite was measured using the Ortego et al. [26] method. A working solution of bovine serum albumin (BSA) was made by diluting the standard BSA solution of $1 \mathrm{mg} / \mathrm{mL}$ to $0.1 \mathrm{mg} / \mathrm{mL}$. In 5 test tubes $200 \mu \mathrm{L}, 400 \mu \mathrm{L}, 600 \mu \mathrm{L}$, $800 \mu \mathrm{L}$, and $1 \mathrm{~mL}$ of the BSA working solution was taken and named 1-5. By adding distilled water, the volume was kept at $1 \mathrm{~mL}$. Only distilled water was used to produce a control. $500 \mu \mathrm{L}$ of the crude extract was collected by Bradford method, and $500 \mu \mathrm{L}$ of sterile distilled water was added to obtain a final volume of $1 \mathrm{~mL}$. The Bradford reagent was added in $5 \mathrm{~mL}$ increments, and the absorbance was measured spectrophotometrically at $595 \mathrm{~nm}$ after $5 \mathrm{~min}$ of incubation. To assess the proteolytic activity of the crude extract, $50 \mu \mathrm{L}$ of BAS $(1 \mathrm{mg} / \mathrm{mL})$ standard solution and roughly $20 \mu \mathrm{L}$ of crude extract were used. The BSA and enzyme were mixed together, and the volume was kept at $200 \mu \mathrm{L}$ by adding phosphate buffer. After $30 \mathrm{~min}, 2.3 \mathrm{~mL}$ of Bradford reagent was added to the mixture. After $5 \mathrm{~min}$, the absorbance was measured against a blank using a spectrophotometer at $595 \mathrm{~nm}$, with two controls: enzyme only and BSA only. The activity of the protease was determined using the Bradford equation [27]. At $\mathrm{pH} 9.0$ at $60{ }^{\circ} \mathrm{C}$, one unit of protease activity is defined as the amount of enzyme that produces $1 \mu \mathrm{mol}$ of tyrosine per minute.

\subsection{Assay of Acetylcholinesterase (AChE) Activity}

Acetylcholinesterase was determined according to $\mathrm{Wu}$ and Miyata [28] with ATCh iodide as a substrate in the presence of 5,5-dithiobis (2-nitrobenzoic acid) DTNB in a $0.066 \mathrm{M}$ phosphate buffer, $\mathrm{pH} 7.8$, at $25^{\circ} \mathrm{C}$. Absorption was measured at $412 \mathrm{~nm}$. The reaction mixture $(2.0 \mathrm{~mL})$ consisted of $0.6 \mathrm{mM} \mathrm{ATCh}, 0.4 \mathrm{mM}$ DTNB and $0.05 \mathrm{~mL}$ aliquot of the enzyme solution.

\subsection{Molecular Docking of E-Anethole in AChE}

The molecular docking was performed using AutoDock 4 [29]. The system was prepared in PyMOL (Schrödinger), using the plug-in developed by Daniel Seeliger (https: / / github.com/ ADplugin/ADplugin, accessed on 15 August 2021). Acetylcholinesterase and Cathepsin L were obtained from the structure of the AChE (6XYU) [30] and Cathepsin L (3F75) [31] complexes. A $54 \times 60 \times 54 \AA$ grid box with $29.488 \times 71.531 \times 12.27$ grid point spacing of $0.375^{\circ} \mathrm{A}$ in the case of Acetylcholine esterase and a $56 \times 54 \times 40 \AA$ grid box with $24.97 \times 18.609 \times 35.567$ grid point spacing of $0.375^{\circ} \mathrm{A}$ in the case of Cathepsin L were employed. The ligands structure was drawn using the PubChem draw structure tool (https:/ / pubchem.ncbi.nlm.nih.gov /\#draw=true, accessed on 15 August 2021). The default parameter set of autodock 4 was used to generate 10 docking poses. The pose with the best energy score was selected as the most representative.

\subsection{Statistical Analysis}

The collected data were calculated as means and standard deviations from three replicates and were analyzed using SPSS statistical software (IBM SPSS Statistics, version 23, New York, NY, USA). The differences between treatments were compared using one-way analysis of variance (ANOVA) according to method of Tamhane and Methods, 1977 [32], post hoc LSD test was also performed at $p \leq 0.000$.

\section{Results}

The results of the chemical composition study of anise seeds are shown in Table 1. The components of anise oil were analyzed using gas chromatography-mass spectrometry 
(GC-MS) to determine the active constituents of anise seed oil. The results were as follows: There are a total of 28 components found in anise oil (see Table 1). The major constituent of anise oil is trans-anethole (53.23\%), followed by estragole (13.52\%) and longifolene $(6.08 \%)$.

Table 1. Chemical composition (\%) in essential oil of Pimpinella anisum analyzed by GC-MS.

\begin{tabular}{cccc}
\hline No Peak & RT $^{\mathbf{1}} \mathbf{( M i n )}$ & Component Names & $\mathbf{\%}^{\mathbf{2}}$ \\
\hline 1 & 5.215 & $\alpha$-Pinene & 0.59 \\
2 & 4.621 & $E$ - $\beta$-Ocimene & 0.93 \\
3 & 5.802 & D-Limonene & 1.00 \\
4 & 6.171 & $\gamma$-Terpinene & 0.60 \\
5 & 6.421 & 3-Carene & 0.93 \\
6 & 6.901 & Linalool & 0.77 \\
7 & 6.958 & $\alpha$-Santalol & 0.70 \\
8 & 7.545 & Estragole & 13.52 \\
9 & 8.147 & Z-Anethole & 1.17 \\
10 & 8.734 & E-anethole & 53.23 \\
11 & 9.099 & $\alpha$-Guaiene & 0.88 \\
12 & 9.238 & 2-Allyl-4-methylphenol & 0.59 \\
13 & 9.372 & (-)-Aristolene & 1.47 \\
14 & 9.501 & Caryophyllene & 1.26 \\
15 & 9.718 & Aromandendrene & 0.56 \\
16 & 9.803 & $\gamma$-Elemene & 1.07 \\
17 & 9.976 & $\alpha$-Himachalene & 1.94 \\
18 & 10.218 & Longifolene & 6.08 \\
19 & 10.358 & Thujopsene & 1.26 \\
20 & 10.489 & Cedrene & 0.80 \\
21 & 11.031 & Ledene & 1.42 \\
22 & 11.354 & Isospathulenol & 0.71 \\
23 & 11.826 & E-Sesquisabinene hydrate & 0.66 \\
24 & 12.683 & E-Isoeugenol & 4.81 \\
25 & 13.048 & Phenol, 2-methoxy-4-(1-propenyl)- & 0.66 \\
26 & 13.676 & Geranyl isovalerate & 0.71 \\
27 & 17.561 & Heptacosane & 0.99 \\
28 & 20.336 & & 0.72 \\
\hline
\end{tabular}

${ }^{1}$ Retention time; ${ }^{2}$ Compound percentage.

The minor constituents in the essential oil of anise seed were cis anethole, D-limonene, $(-)$-aristolene, caryophyllene, $\gamma$-elemene, $\alpha$-himachalene, longifolene, thujopsene and ledene. While seventeen components were present at less than $1 \%$. These were: $\alpha$-pinene $(0.59 \%)$, T- $\beta$-ocimene $(0.93 \%), \gamma$-terpinene $(0.6 \%)$, 3-carene $(0.93 \%)$, linalool $(0.77 \%), \alpha$-santalol $(0.7 \%)$, $\alpha$-guaiene (0.88\%), 2-allyl-4-methylphenol (0.59\%), aromandendrene $(0.56 \%)$, cedrene $(0.8 \%)$, isospathulenol (0.71\%), trans-sesquisabinene hydrate $(0.66 \%)$ trans-isoeugenol ( $4.81 \%)$, phenol, 2-methoxy-4-(1-propenyl)- $(0.66 \%)$, acetophenone, $2^{\prime}, 5^{\prime}$-dimethoxy- $(0.71 \%)$, geranyl isovalerate $(0.99 \%)$ and heptacosane $(0.72 \%)$.

There are usually considerable variations in the major active compounds within this species. The major component of anise oil seen in the current study was trans-anethole, which was similar to major component of many regions of the world. In current research, the main compound of anise oil is trans-anethole followed by estragol.

To evaluate the antioxidant activity of anise oil, the free radical scavenging activity against DPPH was determined. The DPPH assay (Figure 1) showed that the antioxidant activity of anise oil at 10 and $20 \mu \mathrm{L} / \mathrm{mL}$ was approximately $36.02 \pm 2.033 \%$ and $43.62 \pm$ $1.071 \%$, respectively, compared with BHA used as a reference. The antiradical activity percentages of anise oil at 30,40, and $50 \mu \mathrm{L} / \mathrm{mL}$ were $58.12 \pm 1.238 \%, 68.42 \pm 2.007 \%$, and $77.58 \pm 1.044 \%$, respectively. The highest percentage of radical scavenging activity $(77.58 \%)$ was recorded for P. anisum at a concentration of $50 \mu \mathrm{L} / \mathrm{mL}$, followed by a concentration of $40 \mu \mathrm{L} / \mathrm{mL}(68.42 \%)$. It was noticed that as the concentration of any anise extract increased, 
the antioxidant activity also increased, possibly due to the increase in the concentration of the active substances in the oil.

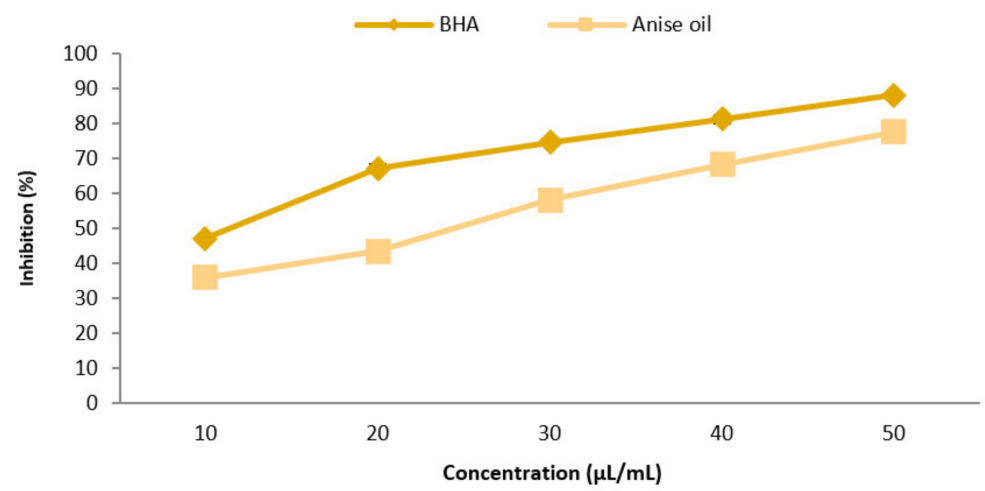

Figure 1. Free radical scavenging activity of essential anise oil (expressed as \% inhibition) compared to Butylated hydroxyanisole (BHA).

Table 2 shows the acaricidal activity of various concentrations of anise oil. The obtained data indicated that five concentrations of anise oil showed remarkable acaricidal effects after 24,48 , and $72 \mathrm{~h}$ of treatment. Anise oil treatments lead to 91.0 and $96.0 \%$ of adult females of T. urticae killed after 48 and $72 \mathrm{~h}$ of treatment with concentrations of $40 \mu \mathrm{L} / \mathrm{L}$. The lowest percentages recorded were $27.30 \%, 28.10 \%$, and $33.00 \%$, respectively, at $10 \mu \mathrm{L} / \mathrm{L}$ after 24, 48, and $72 \mathrm{~h}$. Also, the data clearly indicated that the acaricidal activity of anise oil was increased by increasing both the concentration of the oil and the length of time of the treatment; there were significant differences in the mean values of the tested concentrations on mortality percentages.

Table 2. The mortality percentage of T. urticae as affected by different concentrations of anise oil.

\begin{tabular}{|c|c|c|c|}
\hline \multirow{2}{*}{$\begin{array}{l}\text { Anise Oil Concentration } \\
\qquad(\mu \mathrm{L} / \mathrm{L})\end{array}$} & \multicolumn{3}{|c|}{ Mortality\% of T. urticae } \\
\hline & $24 \mathrm{~h}$ & $48 \mathrm{~h}$ & $72 \mathrm{~h}$ \\
\hline 10 & $27.3 \pm 2.7^{\mathrm{d}}$ & $28.1 \pm 1.0^{\mathrm{d}}$ & $33.0 \pm 1.4^{\mathrm{d}}$ \\
\hline 20 & $42.2 \pm 3.9^{c}$ & $43.9 \pm 1.3^{c}$ & $45.3 \pm 1.8^{c}$ \\
\hline 30 & $70.1 \pm 1.8^{b}$ & $73.9 \pm 4.1^{b}$ & $87.0 \pm 1.5^{b}$ \\
\hline 40 & $89.3 \pm 6.6^{a}$ & $91.0 \pm 1.4^{\mathrm{a}}$ & $96.0 \pm 2.2^{\mathrm{a}}$ \\
\hline Control & 0.000 & 0.000 & 0.000 \\
\hline L.S.D & 0.46 & 0.98 & 0.36 \\
\hline
\end{tabular}

Each value is average of three replicated samples \pm SD. Different letters refer to significant differences at $p \leq 0.000$.

Results (Table 3) revealed that the mean numbers of eggs hatched was not recorded on the first and second days after treatment for all concentrations of oil. Highly significant differences were recorded on the fourth, fifth, and sixth days. Egg hatchability was observed on the third, fourth, fifth, and sixth days for all concentrations. The lowest mean numbers of eggs hatched were recorded at high concentrations of the oil; the findings for $40 \mu \mathrm{L} / \mathrm{L}$ on the fifth and sixth days were $4.75 \pm 0.28$ and $1.25 \pm 0.28$ eggs. The highest values were observed on the third and fourth days at a concentration of $10 \mu \mathrm{L} / \mathrm{L}$ and were $19.75 \pm 0.40$ and $19.5 \pm 0.48$ eggs, respectively.

Figure 2 shows the toxicity of the anise oil at different times against adult females of T. urticae. The recorded $\mathrm{LC}_{50}$ and $\mathrm{LC}_{90}$ values of the anise oil after $72 \mathrm{~h}$ were 20.94 and $35.80 \mu \mathrm{L} / \mathrm{L}$, respectively; the values after $48 \mathrm{~h}$ were 21.73 and $39.99 \mu \mathrm{L} / \mathrm{L}$, respectively; and the values after $24 \mathrm{~h}$ were 22.32 and $43.98 \mu \mathrm{L} / \mathrm{L}$, respectively. These data revealed that the adult females proved to be more susceptible to the toxic action of anise oil after $72 \mathrm{~h}$, followed by $48 \mathrm{~h}$ and $24 \mathrm{~h}$. There was an inverse relationship between the $\mathrm{LC}_{50}$ and LC 90 values and the toxicity of the anise oil. 
Table 3. Mean numbers of eggs hatched into larvae of T. urticae as affected by different concentrations of anise oil.

\begin{tabular}{|c|c|c|c|c|c|c|}
\hline \multirow{2}{*}{ Conc. $(\mu \mathrm{L} / \mathrm{L})$} & \multicolumn{6}{|c|}{ Mean Number of Egg Hatchability \pm SE after Detected Days } \\
\hline & 1st & 2nd & 3rd & 4th & 5th & 6th \\
\hline 10 & 0.00 & 0.00 & $19.75 \pm 0.40^{\mathrm{a}}$ & $19.52 \pm 0.48^{\mathrm{a}}$ & $17.25 \pm 0.37^{\mathrm{a}, \mathrm{b}}$ & $11.25 \pm 0.31^{b}$ \\
\hline 20 & 0.00 & 0.00 & $19.25 \pm 0.28^{a}$ & $16.75 \pm 0.38^{b}$ & $15.25 \pm 0.40^{b}$ & $9.50 \pm 0.29^{b}$ \\
\hline 30 & 0.00 & 0.00 & $16.25 \pm 0.39^{b}$ & $10.75 \pm 0.35^{\mathrm{c}}$ & $9.50 \pm 0.29^{c}$ & $6.25 \pm 0.20^{\mathrm{c}}$ \\
\hline 40 & 0.00 & 0.00 & $10.75 \pm 0.21^{\mathrm{c}}$ & $7.75 \pm 0.28^{\mathrm{d}}$ & $4.75 \pm 0.28^{\mathrm{d}}$ & $1.25 \pm 0.28^{\mathrm{d}}$ \\
\hline Cont. & 0.00 & 0.00 & 117 & $1.52^{19.12}$ & $1.00^{\mathrm{a}} 3.33$ & 179 \\
\hline
\end{tabular}

$\mathrm{LC}_{50}$ and $\mathrm{LC}_{90}$ after 24 hour

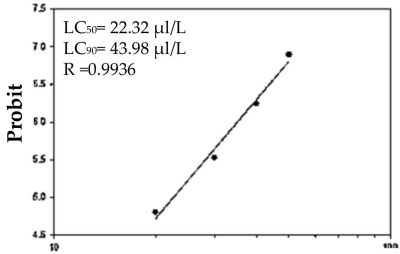

$\log ($ conc) $(\mu \mathrm{l} / \mathrm{L})$

(a)

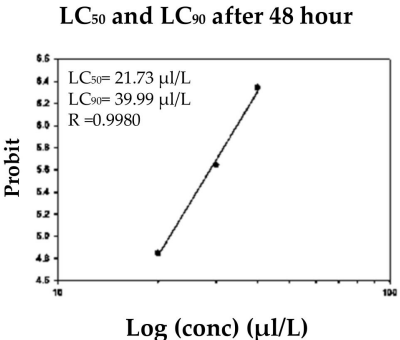

(b)
$\mathrm{LC}_{50}$ and $\mathrm{LC}_{90}$ after 72 hour

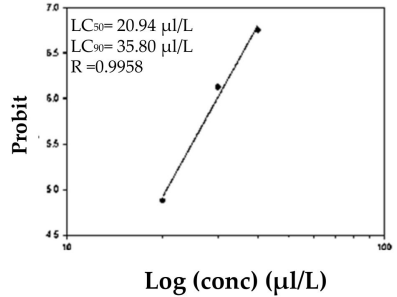

(c)

Figure 2. Toxicity lines of anise oil on adult females of T. urticae after 24,48 , and $72 \mathrm{~h}$ under laboratory conditions. (a) Toxicity lines after 24 h; (b) toxicity lines after 48 h; (c) toxicity lines after $72 \mathrm{~h}$.

The data in Figure 3 show the effect of the anise oil on the protease and AChE activities of the two-spotted spider mites. The results showed that treatment with a low concentration of anise oil $(10 \mu \mathrm{L} / \mathrm{L})$ led to the activation of protease activity by about $2.26 \mu \mathrm{g} / \mathrm{h} / \mathrm{mg}$ protein, and that treatment with $20 \mu \mathrm{L} / \mathrm{L}$ of anise oil did not cause a significant change in protease activity compared with the untreated control. On the other hand, treatment with higher dose of the anise oil, that is, $40 \mu \mathrm{L} / \mathrm{L}$, led to a significant reduction in protease activity by $0.49 \mu \mathrm{g} / \mathrm{h} / \mathrm{mg}$ protein. An experimental result (see Figure 3 ) indicated the AChE activity of T. urticae after $48 \mathrm{~h}$ of exposure to various concentrations of anise oil. The results clearly indicated that anise oil significantly inhibited AChE in a dose-dependent manner. The inhibitory effect of a low dosage of anise oil $(10 \mu \mathrm{L} / \mathrm{L})$ on T. urticae AChE was only about $7.3 \%$. The highest reduction of AChE activity was recorded after $48 \mathrm{~h}$ of treatment with $40 \mu \mathrm{L} / \mathrm{L}$ of anise oil; the AChE activity decreased by $34 \%$ compared with the untreated control.

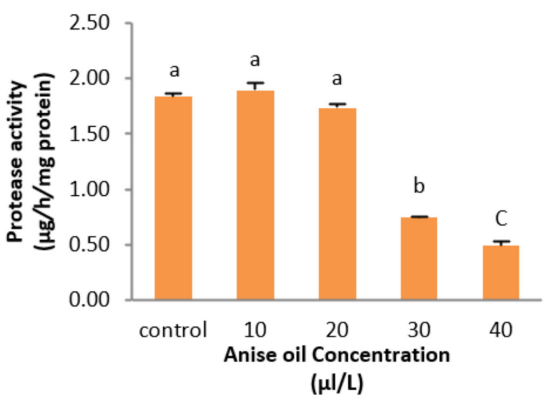

(a)

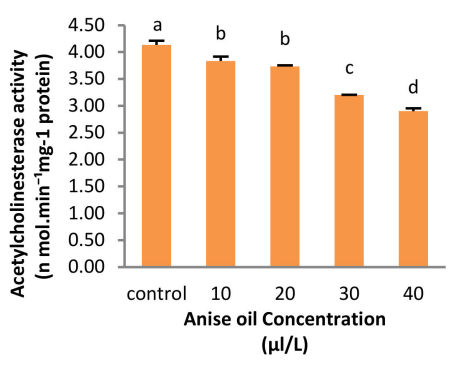

(b)

Figure 3. Enzyme activities of T. urticae subjected to different doses of anise oil. (a) Protease activity; (b) acetylcholinesterase (AChE) activity and for each parameter, the mean values \pm SD followed by a different letter are significantly $(p \leq 0.05)$ different according to LSD.

To study the effect of anise oil on AChE and protease, the main compound in anise oil was selected. Docking was performed with Autodock 4 [29]. Docking of anethole into the active site of AChE (6XYU) [22] showed the presence of hydrophobic interactions between 
anethole; two catalytic residues, His480 and Ser238; three residues of the oxyanion hole, Gly150, Gly151, and Ala239; and the choline-binding pocket Trp83 in the active site of the enzyme. The structures of complexes of AChE with an anethole inhibitor show the importance of these aromatic residues in ligand binding (Figures 4 and 5). The docking of anethole into the active site of cathepsin L (3F75), as one of the protease enzymes in T. urticae, showed the formation of a hydrogen bond between anethole and one residue, Gly74, and hydrophobic interactions between anethole and two catalytic residues, Cys31 and His167, at the active site of the enzyme (see Figure 4).

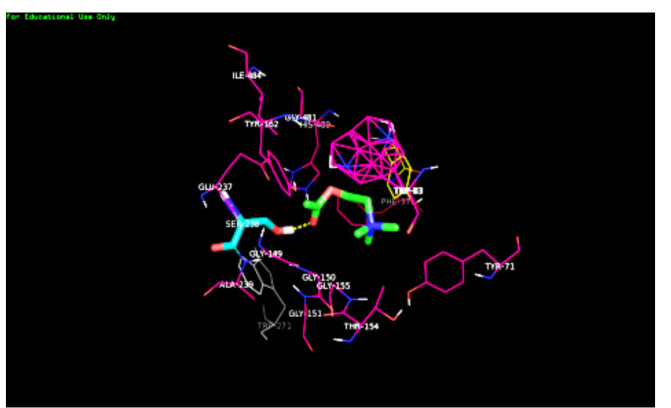

(a)

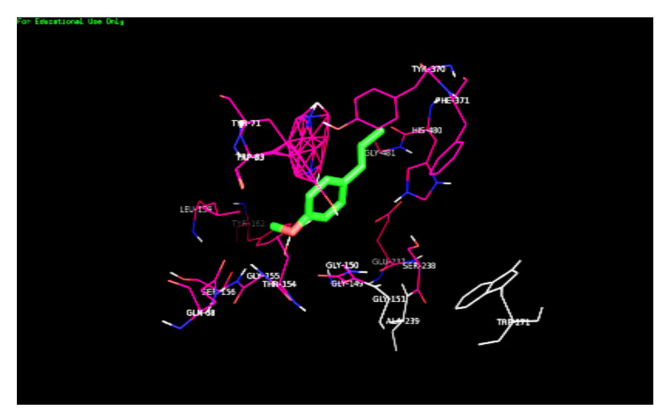

(b)

Figure 4. Structures of the complex of AChE with substrate acetylecholine (a) and updated (b) structures of the complex of AChE with E-anethole (major compound in anise oil). The docking was performed with Autodock. The ligands are represented as sticks in green color; the residues that interacted with the ligand hydrophobicly are represented as lines in pink color; residues that interacted with the ligand with hydrogen bonds are represented as sticks in teal color; non-interactive residues are represented as lines in grey and hydrogen bbonds are represented as yellow dashes.

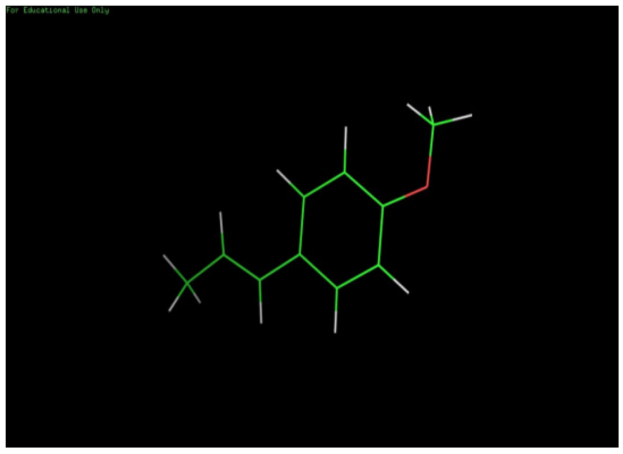

(a)

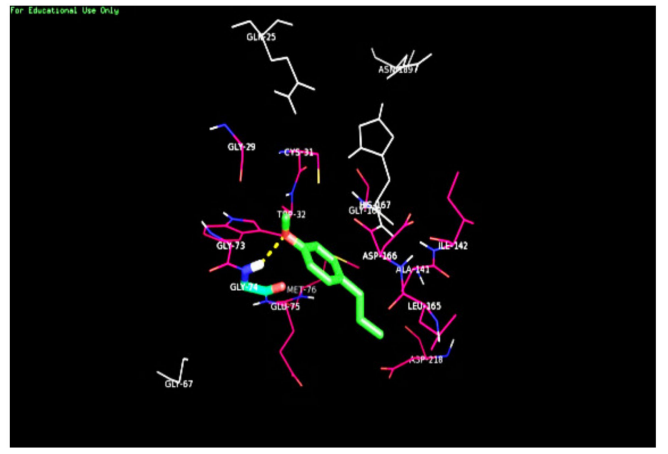

(b)

Figure 5. Structures of E-anethole (a) and updated (b) structures of the complex of Cathepsin L with E-anethole (major compound in anise oil). the ligands are represented as sticks in green color; the residues that interacted with the ligand with hydrophobicly are represented as lines in pink color; residues that interacted with the ligand with hydrogen bonds are represented as sticks in teal color; non-interactive residues are represented as lines in grey and hydrogen bonds are represented as yellow dashes.

\section{Discussion}

In recent years, natural pesticides have become important as alternatives to synthetic pesticides due to the adverse effects of chemical control not only on environment wildlife but also on human health [33]. A lot of studies have been done on the possibility of using natural compounds in plants as an alternative to synthetic pesticides [34,35]. Studies have focused on natural materials that do not add toxic substances to the environment, decompose in a short period of time, and do not cause soil and water pollution [36]. There have been many studies on the effects of extracts from plants obtained by different methods on T. urticae [37]. Several essential oils and plant extracts have insecticidal properties 
including mites [38]. Promising results have been obtained in studies using plant extracts and essential oils in the control of pest mites. Thus, for T. urticae, in trials with spraying on females, Mentha spicata X suaveolens aqueous extract caused the death of $96 \%$ of females after $120 \mathrm{~h}$ of application [39]. oEssential oil of Cymbopogon citratus Boisduval in non-contact diffusion bioassay with oil application in filter paper in a closed container provided $100 \%$ mortality at a dose of $19 \times 10^{-3} \mu \mathrm{L} / \mathrm{mL}$ of air [40].

The variability in the volatile components of anise oil in our results appears to be largely due to the stage of harvest and seasonal and environmental factors, as well as the method of extraction. In anise oil, the main compound was E-anethole, followed by estragole. Similarly, trans-anethole was previously reported as a major component of P. anisum [41,42]. These results are in agreement with previous investigations on anise essential oil [43,44]. Muthanna and Hiyam [45] identified trans-anethole as a major component of P. anisum essential oil (26.97\%), followed by estragole (20.50\%). Haşimi et al. [46] determined that the main components of anise essential oil were trans-anethole $(52.94 \%)$, followed by isoanethole $(13.89 \%)$, caryophyllene oxide $(8.55 \%)$, and caryophyllene $(2.4 \%)$. Mohammed et al. [47] reported that essential oil had a percentage of trans-anethole of $55.491 \%$.

Anise oil showed the highest activity at a concentration of $50 \mu \mathrm{L} / \mathrm{L}$. It was the least effective radical scavenger at a concentration of $10 \mu \mathrm{L} / \mathrm{L}$. This means that by increasing the concentration of the essential oil, the antioxidant activity was increased. This may be due to the increase in terpenes and active substances, which have a free radical scavenging effect. The antioxidant activity of spices and herbs is attributed to the presence of volatile oils and bioactive components [48-50].

According to [51,52], anise oil possesses antioxidant properties. This is due to the fact that the seeds are rich in important minerals and compounds such as anethole, anisaldehyde, anise alcohol, acetophenone, pinene, limonene, and glycerol.

This work has shown that anise oil has acaricidal activity, possibly due to the active substances present in the essential oil. The acaricidal activity assessment reported that anise oil at $40 \mu \mathrm{L} / \mathrm{L}$ could fully control the two-spotted spider mites, with a mortality rate after $72 \mathrm{~h}$ of $96.0 \%$. The highest concentration of anise oil caused the highest mortality rate for $T$. urticae after $24 \mathrm{~h}$. The lowest mean number of eggs hatched at a high concentration of $40 \mu \mathrm{L} / \mathrm{L}$ was recorded during the fifth and sixth days. This may be attributed to the increase in the concentration of active substances, which also increased their effects on egg hatching. The two-spotted spider mite can be controlled with essential oils which possess odor-producing compounds including monoterpenes, sesquiterpenes, phenols, oxides, esters, aldehydes, and ketones [53]. Plants use these active compounds to protect against various arthropods such as insects and mites [54]. Vinicius et al. [5] reported that the most promising extracts for T. urticae control were Origanum vulgare, Matricaria chamomilla, and P. anisum; all produced a mortality rate above $75 \%$ in two replicates. The volatiles emanating from the essential oil, especially carvacrol, borneol, cineol, terpineol, and terpinene, have an acaricidal effect on T. urticae females, reaching a mortality rate of $100 \%$ as a function of concentration and exposure time [55]. In this study, a mortality rate of $96.0 \%$ was obtained when large amounts of essential oils were used. High mortality rates have been reported before; for example, Tunc and Sahinkaya [56] reported a 100\% mortality rate of T. cinnabarinus and Aphis gossypii Glover when essential oils of Cuminum cyminum, P. anisum, and Origanum syriacum were used in greenhouse conditions. In addition to being toxic against the postembryonic stage of insects and mites, some essential oils have oviposition-deterring activities; for example, three essential oils extracted from Laurus nobilis, Myrtus communis, P. anisum, and Artemisia absinthum were toxic against the adults and eggs of T. cinnabarinus under laboratory conditions [57].

The ways essential oils work vary with their neurotoxicity. This confirms why anise oil inhibits the AChE growth in insects, degrading the waxy layers of insect cuticles, which obstruct digestive enzymes such as protease and inhibit glutathione-S-transferase (GST) [58]. Ahmed et al. [58] stated that the compounds (-)-terpinen-4-ol and $\gamma$-terpinene were two main ingredients with insecticidal properties and affected insect enzymes such 
as AChE and GST. This confirms the results of our study; anise seed oil affected various biological parameters of T. urticae such as AChE and protease. Results showed that this oil had a high degree of toxicity against the nervous system, as it inhibited AChE, and the highest inhibition was at a concentration of $40 \mu \mathrm{L} / \mathrm{L}$ after $48 \mathrm{~h}$. This is related to the essential oil's high concentration of E-anethole, which binds to the active site of AChE by hydrophobic interactions (see Figure 3). These results are in agreement with the findings of Ivanov et al. [59], who reported that anise hyssop essential oil showed an inhibitory effect on AChE activity where the IC50 value equaled $19.25 \mathrm{mg} / \mathrm{L}$. Anise oil concentrations of $22.32,21.73$, and 20.94 ppm led to a mortality rate of $50 \%$ of T. urticae mites after 24 , 48 , and $72 \mathrm{~h}$, respectively. The obtained $\mathrm{LC}_{50}$ and $\mathrm{LC}_{90}$ values of anise oil reflect high acaricidal activity of anise oil against T. urticae. Rania [60] found insecticidal activity of lupine extract, olive oil, marjoram oil, anise oil, and orange oil against two strains of $A$. gossypii and Rhopalosiphum maidis (Fitch). Mead [61] stated that the toxic effect of C. citratus oil against T. urticae was undoubtedly due to its component citral (which has two isomers, geranial and neral). The AChE inhibitory activity is due to synergistic and antagonistic interactions between the chemical constituents of anise oil and AChE. The major compound in anise hyssop essential oil was estragol. This compound was reported to have a high ability to inhibit AChE (IC50 $0.337 \mu \mathrm{mol}$ ), followed by eugenol (IC50 $40.32 \mu \mathrm{mol}$ ) [62]. The results of our study indicated that anise oil affected the activity of protease; the exposure of T. urticae adults to anise oil at concentration of $40 \mu \mathrm{L} / \mathrm{L}$ for $48 \mathrm{~h}$ had a significant effect on the protease enzyme compared with the control. This may be attributed to the binding of $E$-anethole to the active site of the enzyme by a hydrogen bond in the residue Gly74 and the hydrophobic interactions between anethole and the catalytic residues Cys31 and His167 at the active site of the enzyme (Figure 4). On the other hand, the treatment of T. urticae with a low concentration of anise oil $(10 \mu \mathrm{L} / \mathrm{L})$ did not cause inhibition of the protease activity. Accordingly, it can be concluded that the increase in the anise oil concentration had a paradoxical impact on the protease activity. In addition to the above findings, effective compounds have been identified in the essential oils of thyme and anise and synergistic activity has been shown [63]. Hummelbrunner and Isman [64] reported that monoterpenes produce synergistic insecticidal effects. The Chaubey [65] study reported that $\alpha$-pinene and $\beta$-caryophyllene in a binary combination showed synergy, reduced the egg-laying capacity, and prevented pupation and adult emergence in Tribolium castaneum. These results reported earlier clearly support the results of the current study. In the current research, anise oil (P. anisum) was more effective against T. urticae. The presence of bioactive components in anise oil provides hope for the development of new natural insecticides that would be economically and environmentally sound for the management of insect pests that affect stored products. The present findings confirmed the findings of Athanase and Fedai [66] and Ahmed et al. [58]. Gas chromatography analysis for volatile oils showed that bisabolol oxide A (44.34\%), carvone (70.29\%), linalool (85.60\%), and camphor $(54.36 \%)$ were the main components of chamomile, spearmint, coriander, and rosemary volatile oils, respectively, and they may be responsible for controlling T. urticae. Anise oil contains most of these active substances, and it had the same effect on T. urticae. In addition to the effect of the main compound, E-anethole, on the inhibition of AChE and protease enzymes. The inhibition was competitive for the active site.

\section{Conclusions}

In conclusion, anise oil caused high mortality rates in T. urticae mites at different times with a concentration of $40 \mu \mathrm{L} / \mathrm{L}$. The lowest mean number of eggs hatched was recorded at the high concentration of $40 \mu \mathrm{L} / \mathrm{L}$ on the fifth and sixth days of the study. The results showed that the activity of $\mathrm{AChE}$ was significantly inhibited at $40 \mu \mathrm{L} / \mathrm{L}$, followed by $30 \mu \mathrm{L} / \mathrm{L}$. This is related to the essential oil's high concentration of $E$-anethole, which binds to the active site of the AChE enzyme by hydrophobic interactions. The activities of protease decreased when mites were treated with 30 or $40 \mu \mathrm{L} / \mathrm{L}$ of anise oil. This is related to the essential oil's high concentration of active compounds such as E-anethole, 
-(e)-isoeugenol, limonene, linalool, and $\alpha$-pinene. Therefore, we suggest that tested anise oil can be used to control mites on green bean seedlings as an alternative to harmful insecticides. Due to the devastating effects of synthetic insecticides on humans and the environment, the use of anise oil as a natural pesticide is advised.

Author Contributions: Conceptualization S.M.E.-S., N.A., H.M.E., M.A.R.I.; methodology, S.M.E.-S., N.A., S.S. (Samy Selim), A.A.A.-K., N.E.N., H.M.E., M.A.R.I.; validation, S.M.E.-S., N.A., H.M.E., M.A.R.I.; formal analysis, S.M.E.-S., N.A., S.S. (Samy Sayed), H.M.E., M.A.R.I.; investigation, S.S. (Samy Selim), A.A.A.-K., N.E.N., S.H.A.-H., S.S. (Samy Sayed); resources, S.M.E.-S., N.A., S.S. (Samy Selim), A.A.A.-K., N.E.N., S.H.A.-H., S.S. (Samy Sayed), H.M.E., M.A.R.I.; data curation, S.M.E.-S., N.A., S.S. (Samy Selim), A.A.A.-K., N.E.N., S.H.A.-H., S.S. (Samy Sayed), H.M.E., M.A.R.I.; writingoriginal draft preparation, S.M.E.-S., N.A., H.M.E., M.A.R.I.; writing-review and editing, S.M.E.-S., N.A., S.S. (Samy Selim), A.A.A.-K., N.E.N., S.H.A.-H., S.S. (Samy Sayed), H.M.E., M.A.R.I.; supervision, S.M.E.-S., N.A., S.S. (Samy Selim), A.A.A.-K., N.E.N., S.H.A.-H., S.S. (Samy Sayed), H.M.E., M.A.R.I.; project administration, S.H.A.-H., S.S. (Samy Sayed), H.M.E., M.A.R.I.; funding acquisition, S.M.E.-S., N.A., S.S. (Samy Selim), A.A.A.-K., N.E.N., S.H.A.-H., S.S. (Samy Sayed), H.M.E., M.A.R.I. All authors have read and agreed to the published version of the manuscript.

Funding: This research received no external funding.

Institutional Review Board Statement: Not applicable.

Informed Consent Statement: Not applicable.

Data Availability Statement: Not applicable.

Acknowledgments: The authors would like to thank Princess Nourah bint Abdulrahman University Researchers supporting Project number (PNURSP2022R37), Princess Nourah bint Abdulrahman University, Riyadh, Saudi Arabia. The authors would like to thank Taif University Researchers Supporting Project number (TURSP-2020/92), Taif University, Taif, Saudi Arabia.

Conflicts of Interest: The authors declare no conflict of interest.

\section{References}

1. Migeon, A.; Dorkeld, F. Spider Mites Web: A comprehensive database for the Tetranychidae. Trends Acarol. 2010, 557-560.

2. De Carvalho Ribeiro, N.; da Camara, C.A.G.; de Melo, J.P.R.; de Moraes, M.M. Effect of the essential oil from the latex of the fruit Mangifera indica L. on Tetranychus urticae Koch (Acari, Tetranychidae). Acarologia 2019, 59, 335-347. [CrossRef]

3. Nicastro, R.L.; Sato, M.E.; Arthur, V.; Silva, M.Z. Chlorfenapyr resistance in the spider mite Tetranychus urticae: Stability, cross-resistance and monitoring of resistance. Phytoparasitica 2013, 41, 503-513. [CrossRef]

4. Reis, P.R.; Franco, R.A.; Pedro-Neto, M.; Teodoro, A.V. Selectivity of agrochemical son predatory mites (Phytoseiidae) found on coffee plants. Coffee Sci. 2006, 1, 64-70.

5. Vinicius, G.T.; Marineide, R.V.; Gustavo, L.M.M.; Cristiane, G.N. Plant extracts with potential to control of two-spotted spider mite. Arq. Inst. Biológico 2018, 85, e0762015.

6. Hayes, W.J.; Laws, E.R. Hand Book of Pesticide Toxicology; Academic Press: San Diego, CA, USA, 1991; Volume 1.

7. Gaber, A.; Alsanie, W.F.; Kumar, D.N.; Refat, M.S.; Saied, E.M. Novel Papaverine Metal Complexes with Potential Anticancer Activities. Molecules 2020, 25, 5447. [CrossRef]

8. Regnault-Roger, C.; Vincent, C.; Arnason, J.T. Essential oils in insect control: Low-risk products in a high-stakes world. Annu. Rev. Entomol. 2012, 57, 405-425. [CrossRef]

9. Sharar, M.; Saied, E.M.; Rodriguez, M.C.; Arenz, C.; Montes-Bayón, M.; Linscheid, M.W. Elemental Labelling and Mass Spectrometry for the Specific Detection of Sulfenic Acid Groups in Model Peptides: A Proof of Concept. Anal. Bioanal. Chem. 2017, 409, 2015-2027. [CrossRef]

10. Moustafa-Farag, M.; Mohamed, H.I.; Mahmoud, A.; Elkelish, A.; Misra, A.N.; Guy, K.M.; Kamran, M.; Ai, S.; Zhang, M. Salicylic Acid Stimulates Antioxidant Defense and Osmolyte Metabolism to Alleviate Oxidative Stress in Watermelons under Excess Boron. Plants 2020, 9, 724. [CrossRef]

11. Isman, M.B. Commercial development of plant essential oils and their constituents as active ingredients in bioinsecticides. Phytochem. Rev. 2020, 19, 235-241. [CrossRef]

12. Gaber, A.; Refat, M.S.; Belal, A.A.M.; El-Deen, I.M.; Hassan, N.; Zakaria, R.; Alhomrani, M.; Alamri, A.S.; Alsanie, W.F.; Saied, E.M. New Mononuclear and Binuclear Cu(II), Co(II), Ni(II), and Zn(II) Thiosemicarbazone Complexes with Potential Biological Activity: Antimicrobial and Molecular Docking Study. Molecules 2021, 26, 2288. [CrossRef] [PubMed]

13. Ebadollahi, A. Plant Essential Oils from Apiaceae Family as Alternatives to ConventionalInsecticides. Ecol. Balk. 2013, 5, 149-172. 
14. Amini, S.; Tajabadi, F.; Khani, M.; Labbafi, M.R.; Tavakoli, M. Identification of the seed essential oil composition of four apiaceae species and comparison of their biological effects on Sitophilus oryzae L. and Tribolium castaneum (Herbst.). J. Med. Plant 2018, 17, 68-76.

15. Saleh, A.A.H.; Abdel-Kader, D.Z.; El Elish, A.M. Role of Heat Shock and Salicylic Acid in Antioxidant Homeostasis in Mungbean (Vigna Radiata L.) Plant Subjected to Heat Stress. Am. J. Plant Physiol. 2007, 2, 344-355. [CrossRef]

16. Lucca, P.S.R.; Nobrega, L.H.P.; Alves, L.F.A.; Cruz-Silva, C.T.A.; Pacheco, F.P. The insecticidal potential of Foeniculum vulgare Mill., Pimpinella anisum L. and Caryophillus aromaticus L. to control aphid on kale plants. Rev. Bras. Plantas Med. 2015, 17, 585-591. [CrossRef]

17. Knio, K.M. Larvicidal activity of essential oils extracted from commonly used herbs in Lebanon against the seaside mosquito, Ochlerotatus Caspius. Bioresour. Technol. 2007, 99, 763-768. [CrossRef]

18. Robles-Bermúdez, A.; Candelario, S.O.; Rodríguez-Maciel, C.; Gómez-Aguilar, J.R.; Isiordia-Aquino, N.; Pérez-González, R. Traps Treated with Pimpinella anisum, as Attractant of Thrips (Thysanoptera: Thripidae) in Rose. Rev. Mex. Cienc. Agrícolas 2011, $31,555-563$.

19. Koul, O.; Walia, S.; Dhaliwal, G.S. Essential oils as green pesticides: Potential and constraints. Jpn. Biopestic. Int. 2008, 4, 63-84.

20. Patricia, M.S.; Migdalia, M.; Juan, A.P.; Mario, S.; Víctor, H.; Esther, P. Gas Chromatography-Mass Spectrometry Study from the Leaves Fractions Obtained of Vernonanthura patens (Kunth) H. Rob. Int. J. Org. Chem. 2013, 3, 105-109.

21. Gargouri, W.; Osés, S.M.; Fernández-Muiño, M.A.; Sancho, M.T.; Kechaour, N. Evaluation of bioactive compounds and biological activities of Tunisian propolis. LWT-Food Sci. Technol. 2019, 111, 328-336. [CrossRef]

22. Pritam, S.; Clare, G.K. A Method for Continuous Production of Diapausing Two-Spotted Mite in the Laboratory; The Horticulture and Food Research Institute of New Zealand: Auckland, New Zealand, 1993; Volume 16.

23. Abbott's, W.S.A. Method of computing the effectiveness of an insecticide. J. Econ. Entomol. 1925, 18, 265-267. [CrossRef]

24. Finney, D.J. Probit Analysis a Statistical Treatment of the Sigmoid Response Curve; Cambridge University Press: Cambridge, UK, 1952; 318p

25. Systat Software, Inc. Sigma Plot Version 2.0. 1996. Available online: www.systatsoftware.com (accessed on 20 December 2021).

26. Ortego, F.; Novillo, C.; Castañera, P. Characterization and distribution of digestive proteases of the stalk corn borer, Sesamia nonagrioides Lef. (Lepidoptera: Noctuidae). Arch. Insect Biochem. Physiol. 1996, 33, 163-180. [CrossRef]

27. Bradford, M.M. A rapid and sensitive for the quantitation of microgram quantitites of protein utilizing the principle of protein-dye binding. Anal. Biochem. 1967, 72, 248-254. [CrossRef]

28. Wu, G.; Miyata, T. Susceptibilities to methamidophos and enzymatic characteristics in 18 species of pest insects and their natural enemies in crucifer vegetable crops. Pestic. Biochem. Physiol. 2005, 82, 79-93. [CrossRef]

29. Morris, G.M.; Huey, R.; Lindstrom, W.; Sanner, M.F.; Belew, R.K.; Goodsell, D.S.; Olson, A.J. AutoDock4 and AutoDockTools4: Automated docking with selective receptor flexibility. J. Comput. Chem. 2009, 30, 2785-2791. [CrossRef]

30. Nachon, F.; Terrone, L.R.; Israel, S.; Joel, L.S. A Second Look at the Crystal Structures of Drosophila melanogaster Acetylcholinesterase in Complex with Tacrine Derivatives Provides Insights Concerning Catalytic Intermediates and the Design of Specific Insecticides. Molecules 2020, 25, 1198. [CrossRef]

31. Larson, T.E.; Fabiola, P.; My-Hang, H.; Jonathan, D.G.; Angela, M.K.; Li, Z.; Matthew, B.; Ethan, A.M.; Vern, B.C. Toxoplasma gondii Cathepsin L Is the Primary Target of the Invasion-inhibitory Compound Morpholinurea-leucylhomophenyl-vinyl Sulfone Phenyl. J. Biol. Chem. 2009, 284, 26839-26850. [CrossRef]

32. Tamhane, A.C. Multiple comparisons in model I one-way ANOVA with unequal variances. Commun. Stat.-Theory Methods 1977, 6 , 15-32. [CrossRef]

33. Laborda, R.; Manzano, I.; Gamon, M.; Gavidia, I.; Perez-Bermudez, P.; Boluda, R. Effects of Rosmarinus officinalis and Salvia officinalis essential oils on Tetranychus urticae Koch (Acari: Tetranychidae). Ind. Crops Prod. 2013, 48, 106-110. [CrossRef]

34. Cavalcanti, S.C.H.; Niculau, E.S.; Blank, A.F.; Camara, C.A.G.; Araujo, I.N.; Alves, B.P. Composition and acaricidal activity of Lippia sidoides essential oils against two spotted spider mite (Tetranychus urticae Koch). Bioresour. Technol. 2010, 101, 829-832. [CrossRef]

35. Wei, J.; Ding, W.; Zhao, Y.G.; Vanichpakorn, P. Acaricidal activity of Aloe vera L. leaf extracts against Tetranychus cinnabarinus (Boisduval) (Acarina: Tetranychidae). J. Asia-Pac. Entomol. 2011, 14, 353-356. [CrossRef]

36. Isman, M.B.; Akhtar, Y. Plant Natural Products as a Source for Developing Environmentally Acceptable Insecticides. In Insecticides Design Using Advanced Technologies; IIshaaya, I., Nauen, R., Eds.; Springer: Berlin/Heidelberg, Germany, 2007; pp. 235-248.

37. Chermenskaya, T.D.; Stepanycheva, E.A.; Shchenikova, A.V.; Chakaeva, A.S. Insec to acaricidal and deterrent activities of extracts of Kyrgyzstan plants against three agricultural pests. Ind. Crops Prod. 2010, 32, 157-163. [CrossRef]

38. Attia, S.; Grissa, L.K.; Lognay, G.; Bitume, E.; Hance, T.; Mailleux, A.C. A review of the major biological approaches to control the worldwide pest Tetranychus urticae (Acari: Tetranychidae) with special reference to natural pesticides Biological approaches to control Tetranychus urticae. J. Pest Sci. 2013, 86, 361-386. [CrossRef]

39. Vieira, M.R.; Sacramento, L.V.S.; Furlan, L.O.; Figueira, J.C.; Rocha, A.B.O. Efeito acaricida de extratos vegetais sobre fêmeas de Tetranychus urticae Koch (Acari: Tetranychidae). Rev. Bras. Plantas Med. 2006, 8, 210-217.

40. Choi, W.I.; Lee, S.G.; Park, H.M.; Ahn, Y.J. Toxicity of plant essential oils to Tetranychus urticae (Acari: Tetranychidae) and Phytoseiulus persimilis (Acari: Phytoseiidae). J. Econ. Entomol. 2004, 97, 553-558. [CrossRef]

41. Habib, U.; Athar, M.; Bernd, H. Essential oil and composition of anise (Pimpinella anisum L.) with varying seed rates and row spacing. Pak. J. Bot. 2014, 46, 1859-1864.

42. Ullah, H.; Mahmood, A.; Ijaz, M.; Tadesse, B.; Honermeier, B. Evaluation of anise (Pimpinella anisum L.) accessions with regard to morphological characteristics, fruit yield, oil contents and composition. J. Med. Plants Res. 2013, 7, 177-2186. 
43. Orav, A.; Raal, A.; Arak, E. Essential oil composition of Pimpinella anisum L., fruits from various European countries. Nat. Prod. Res. 2008, 22, 227-232. [CrossRef]

44. Yan, F.; Beyer, M.E.; Azizi, A.; Honermeier, B. Effect of sowing time and sowing density on fruit yield, essential oil concentration and composition of anise (Pimpinella anisum L.) under field conditions in Germany. J. Med. Spice Plants 2011, 16, 26-33.

45. Muthanna, J.M.; Hiyam, A.E. Gas Chromatography-Mass Spectrometry Profiling of Pimpinella anisum Oils and its Antimicrobial and Antioxidant Activities. Int. J. Pharm. Qual. Assur. 2020, 11, 257-261.

46. Hasimi., A.; Tolan, V.; Kizil, S.; Kilinc, E. Determination of essential oil composition, antimicrobial and antioxidant properties of anise (Pimpinella anisum L.) and cumin (Cuminum cyminum L.) seeds. J. Agric. Sci. 2014, 20, 19-26.

47. Mohammed, S.; Albulushi, A.; Al Saidi, H.; Amaresh, N.; Mullaicharam, A.R. Study of physicochemical properties, antibacterial and GC-MS analysis of essential oil of the aniseed (Pimpinella anisum Linn.) in Oman. J. Pharmacogn. Phytochem. 2014, 2, 24-33.

48. Singh, G.; Marimuthu, P. Antioxidant and biocidal activities of Carum nigrum (seed) essential oil, oleoresin, and their selected components. J. Agric. Food Chem. 2006, 54, 174-181. [CrossRef]

49. Yadegarinia, D.; Gachkar, L.; Rezaei, M.; Taghizadeh, M.; Astaneh, S.; Rasooli, I. Biochemical activities of Iranian Mentha piperita L. and Mentha communis L. essential oils. Phytochemistry 2006, 67, 1249-1255. [CrossRef]

50. Majhenic, L.; Skerget, M.; Knez, Z. Antioxidant and antimicrobial activity of guarana seed extracts. Food Chem. 2007, 104, 1258-1268. [CrossRef]

51. Lopez-Bote, L.; Gray, J.I.; Gomaa, E.A.; Fle Gal, C.I. Effect of dietary administration of oil extracts from rosemary and sage on lipid oxidation in broiler meat. Poult. Sci. 1998, 39, 235-240. [CrossRef]

52. Rabha, M.G.K.; Nazar, M.G.; Ali, A.E. Identification of Anise Seed Oils and their Antimicrobial and Antioxidant Activities Red Sea Univ. J. Basic Appl. Sci. 2017, 2, 232-243.

53. De Carvalho Brito, R.; da Silva Fontes, L.; Soares da Silva, P.H.; de Sousa Santana, C.; e Silva Barbosa, D.R. Essential oils from Betula lenta, Cinnamomum cassia, Citrus aurantium var. Amara and Acorus calamus as biopesticides against cowpea weevil. Int. J. Trop. Insect Sci. 2022, 42, 261-268. [CrossRef]

54. Park, Y.-L.; Tak, J.-H. Essential Oils for Arthropod Pest Management in Agricultural Production Systems. In Essential Oils in Food Preservation, Flavor and Safety; Elsevier: Amsterdam, The Netherlands, 2016; pp. 61-70. ISBN 978-0-12-416641-7.

55. Çalmasur, O.; Aslan, I.; Şahin, F. Insecticidal and acaricidal effect of three Lamiaceae plant essential oils against Tetranychus urticae Koch and Bemisia tabaci Genn. Ind. Crops Prod. 2006, 23, 140-146. [CrossRef]

56. Tunc, I.; Sahinkaya, S. Sensitivity of Two Greenhouse Pest to Vapour of Essential Oils. Entomol. Exp. Appl. 1998, 86, 183-187. [CrossRef]

57. Topuz, E.; Erler, F. Bioefficacy of Some Essential Oils against the Carmine Spider Mite, Tetranychus cinnabarinus. Fresenius Environ. Bull. 2007, 16, 1498-1502.

58. Ahmed, Q.; Agarwal, M.; Al-Obaidi, R.; Wang, P.; Ren, Y. Evaluation of Aphicidal Effect of Essential Oils and Their Synergistic Effect against Myzus persicae (Sulzer) (Hemiptera: Aphididae). Molecules 2021, 26, 3055. [CrossRef]

59. Ivanov, I.G.; Radka, Z.V.; Nadezhda, T.P.; Yulian, T.; Ivayla, N.D.; Ilian, K.B. Phytochemical compounds of anise hyssop (Agastache foeniculum) and antibacterial, antioxidant, and acetylcholinesterase inhibitory properties of its essential oil. J. Appl. Pharm. Sci. 2019, 9, 72-78.

60. Rania, H.M. Toxicity and Biochemical Effect of some Plant Extracts Against The Two-Spotted Spider mite (Tetranychus urticae Koch). (Acari: Tetranychidae). Plant Arch. 2020, 20, 5450-5454.

61. Hala, M.L.M. Acaricidal activity of essential oil of lemongrass, Chymbopogon citratus (DC.) Stampe against Tetranychus urticae (Koch). J. Plant Prot. Pathol. 2012, 3, 43-51.

62. Farag, M.A.; Ezzat, S.M.; Salama, M.M.; Tadros, M.G.; Serya, R.A.T. Anti-acetylcholinesterase activity of essential oils and their major constituents from four Ocimum species. Z. Fur Nat. Sect. C J. Biosci. 2016, 71, 393-402. [CrossRef]

63. Youssef, N.S. Toxic and synergistic properties of several volatile oils against larvae of the house fly, Musca domestica vicina Maquart (Diptera: Muscidae). J. Basic Appl. Zool. 1997, 22, 131-149.

64. Hummelbrunner, L.; Isman, M.B. Acute, sublethal, antifeedant and synergistic effects of monoterpenoid essential oil compounds on the tobacco cut worms, Spodoptera litura (Lep., Noctuidae). J. Agric. Food Chem. 2001, 49, 715-720. [CrossRef]

65. Chaubey, M.K. Acute, Lethal and Synergistic Effects of Some Terpenes Against Tribolium castaneum Herbst (Coleoptera: Tenebrionidae). Ecol. Balk. 2012, 4, 53-62.

66. Athanase, H.; Fedai, E. Fecundity and fertility inhibition efects of some plant essential oils and their major components against Acanthoscelides obtectus Say (Coleoptera: Bruchidae). J. Plant Dis. Prot. 2020, 127, 615-623. 